\title{
Mineral fibres, fibrosis, and asbestos bodies in lung tissue from deceased asbestos cement workers
}

\author{
M Albin, L Johansson, F D Pooley, K Jakobsson, R Attewell, R Mitha
}

\begin{abstract}
Lung tissue from 76 deceased asbestos cement workers (seven with mesothelioma) exposed to chrysotile asbestos and small amounts of amphiboles, has been studied by transmission electron microscopy, together with lung tissue from 96 controls. The exposed workers with mesothelioma had a significantly higher total content of asbestos fibre in the lungs than those without mesothelioma, who in turn, had higher concentrations than the controls (medians 189, 50 , and $29 \times 10^{6}$ fibres $\left./ g(f / g)\right)$. Chrysotile was the major type of fibre. The differences were most pronounced for the amphibole fibres (62, $4 \cdot 7$, and $0 \cdot 15 \mathrm{f} / \mathrm{g})$, especially crocidolite $(54,1 \cdot 8$ and $<0.001 \mathrm{f} / \mathrm{g}$ ), but were evident also for tremolite $(2.9,<0.001$, and $<0.001 \mathrm{f} / \mathrm{g})$ and anthophyllite $(1 \cdot 7,<0.001$, and $<0.001 \mathrm{f} / \mathrm{g})$. For amosite, there was no statistically significant difference between lungs from workers with and without mesothelioma; the lungs of workers had, however, higher concentrations than the controls. Strong correlations were found between duration of exposure and content of amphibole fibres in the lungs. Asbestos bodies, counted by light microscopy, were significantly correlated with the amphibole but not with the chrysotile contents. Fibrosis was correlated with the tremolite but not the chrysotile content in lungs from both exposed workers and controls. Overall, similar results were obtained using fibre counts and estimates of mass.
\end{abstract}

Exposure to asbestos can be verified and quantified microscopically in lung tissue by counting of asbestos bodies $^{1}$ or by determination of actual content of

\footnotetext{
Department of Occupational and Environmental Medicine

M Albin, $\mathrm{K}$ Jakobsson, $\mathrm{R}$ Attewell

and Department of Pathology, University Hospital, S-221 85 Lund, Sweden

L Johansson

School of Engineering, University of Wales, College of Cardifi, Wales

F D Pooley, R Mitha
}

fibre. ${ }^{2}$ A large proportion of asbestos workers are exposed in the production of asbestos cement. This industry is the world's major consumer of raw asbestos; mainly chrysotile. ${ }^{3}$ The interpretation of the findings on the lung burden of chrysotile in exposed workers is, however, not clear. Thus chrysotile seems not to accumulate in lung tissue to the same extent as the other types of asbestos. The reason for this is not known, but is assumed to be due to a higher clearance rate rather than a difference in deposition. ${ }^{4}$

It has been suggested ${ }^{5}$ that fibrosis might be associated with fibre mass, rather than with fibre counts, which would take into account the possible splitting up of fibre bundles (mainly chrysotile) in the filter preparation, as well as the finer and shorter average fibre dimensions in chrysotile compared with amphibole asbestos. To our knowledge, no such study has been published. This aspect would be most important in work where the average fibre length tends to be shorter and fibre bundles tend to be disintegrated. This applies to the asbestos cement industry, which does not use the long fibres necessary in textiles, and in which the asbestos is sometimes milled before mixing.

Only one study ${ }^{6}$ has been published on the content of mineral fibre in lung tissue among asbestos cement workers, showing high concentrations of amphiboles. The eight cases analysed had, however, suffered from mesothelioma or bronchogenic carcinoma and may thus have been selected for exposure or retention of amphiboles within the work force.

In a cohort study of asbestos cement workers, ${ }^{7}$ we found an increased risk of pleural mesothelioma, lung cancer, colorectal cancer, and non-malignant respiratory disease with surprisingly steep dose response relations similar to the ones observed in the asbestos textile industry, ${ }^{89}$ and in one of the asbestos cement industries previously studied. ${ }^{10}$ These dose response relations were, however, much steeper than those found in other asbestos cement industries ${ }^{11-13}$ as well as in chrysotile mines. ${ }^{14}$

It was thus of interest to scrutinise the lungs from deceased workers in our cohort. A dose response relation existed between estimated exposure to asbestos (fibre-years $/ \mathrm{ml}$ ) on the one hand, and asbestos bodies and lung fibrosis on the other. ${ }^{1}$ Counts of 
asbestos bodies, however, represent only a rough estimate of the fibre content in lung tissue, indicating only a part of the fibres, as these bodies form mainly on crocidolite and amosite, and only rarely on chrysotile. Analyses by transmission electron microscopy (TEM), which has high resolution, was therefore of special interest in order to quantify the total lung burden of asbestos as well as the particular types of asbestos. Also, at low dose of exposure, nonasbestos fibres might be of importance as possible confounders for fibrosis. Such data are reported here.

\section{Material and methods}

\section{PLANT AND EXPOSURE}

Asbestos cement products were made at the plant during the period 1907-77. Chrysotile was the major type of asbestos used ( $>95 \%$ ). Until 1966, small amounts of crocidolite were used in certain products (often $<1 \%$, never exceeding 3-4\%). Small amounts of amosite were used until 1956 with a maximum purchase of $17 \%$ of the total in 1948-9, and a stated use of $1 \%$ in 1953-6. All asbestos was milled before mixing.

The highest estimated time weighted average value was $10 \mathrm{fibres} / \mathrm{ml}(\mathrm{f} / \mathrm{ml})$ for millers until 1952 . During the 1970 s the highest exposure concentration was $4 \mathrm{f} / \mathrm{ml}$. The only workers continuously exposed to average concentrations above $2 \mathrm{f} / \mathrm{ml}$ were millers, mixers, and workers engaged in polishing and sawing operations. Occasional exposure to very high dust concentrations occurred during unloading and storing of asbestos bags.

\section{LUNG SPECIMENS}

Pulmonary fibrosis and counts of asbestos bodies determined by light microscopy for 89 asbestos cement workers and controls, individually matched for sex, age ( \pm 5 years), and year and place of death, have been reported previously. ${ }^{1}$ Lung tissue for further analysis was available for 69 of the exposed workers, and for all of the 89 controls, which together comprise the material for this study (table 1). In three cases, asbestosis was given as the cause of death on the death certificate. The tissue was fixed in formalin and embedded in paraffin.

Lung tissue from another seven asbestos cement workers with pleural mesothelioma was also examined for mineral fibres together with seven individually matched controls. These pairs were not included in the histological study. The histopathological and immunohistochemical characteristics of the cases of mesothelioma have been described elsewhere. ${ }^{7}$

\section{ANALYSIS}

The tissue specimens (average dry weight $25 \mathrm{mg}$ ) were digested chemically. The number of fibres per gram dry weight, fibre length, and fibre diameter were determined using TEM. Type of fibre (asbestos or other fibres), as well as type of asbestos, was determined by energy dispersive $x$ ray spectrometry. The analysis was performed "blindly", analysing tissue from exposed workers and controls in random order. For all specimens, at least two separate sets of measurements were made and for six specimens three separate ones. The average of the results from each subject was used as the basic unit in the statistical analysis. The estimates of mass for the different components were calculated from fibre length, diameter, shape, and specific gravity. ${ }^{15}$

Asbestos bodies were examined in unstained sections of $25 \mu$ thickness and interstitial fibrosis was scored $0-4$ according to the classification proposed by Hinson et al. ${ }^{16}$

\section{STATISTICS}

The original pairs were dissolved, as paired and unpaired analysis gave similar results. Because the distribution of the fibre contents was generally skew, non-parametric methods were used for analysis when possible. The median and range are quoted as descriptive statistics. The Mann-Whitney U test was used to compare concentrations of fibre or mass estimates between the groups and Kendall's test was used to evaluate rank correlates between fibre concentration or mass estimate and several variables (employment time, fibrosis grade, amount of smok-

Table 1 Mean age, year of first employment, duration of employment, and time between end of exposure and death for asbestos cement workers and controls (range in parentheses)

\begin{tabular}{|c|c|c|c|c|}
\hline \multirow[b]{2}{*}{ Parameter } & \multicolumn{2}{|l|}{ Asbestos cement workers } & \multicolumn{2}{|l|}{ Controls } \\
\hline & Without mesothelioma & With mesothelioma & Total & With histology \\
\hline $\begin{array}{l}\text { No } \\
\text { Age (y) } \\
\text { Year of first employment } \\
\text { Duration of employment }(y)\end{array}$ & $\begin{array}{l}69 \\
69(38-91) \\
1944(1911-1969) \\
15(0 \cdot 25-47)\end{array}$ & $\begin{array}{l}7 \\
68(42-85) \\
1931(1919-1946) \\
\quad 31(23-38)\end{array}$ & $\begin{array}{l}96 \\
67(37-93) \\
-\end{array}$ & $\begin{array}{l}89 \\
67(37-93) \\
-\end{array}$ \\
\hline $\begin{array}{l}\text { Cumulated asbestos exposure } \\
\text { (fibre-years/ml) mean } \\
\text { median } \\
\text { Time since end of exposure (y) }\end{array}$ & $\begin{array}{l}26(0-230) \\
13(0-230) \\
12(0-36)\end{array}$ & $\begin{array}{c}49(14-162) \\
28(14-162) \\
6(0-18)\end{array}$ & E & - \\
\hline
\end{tabular}



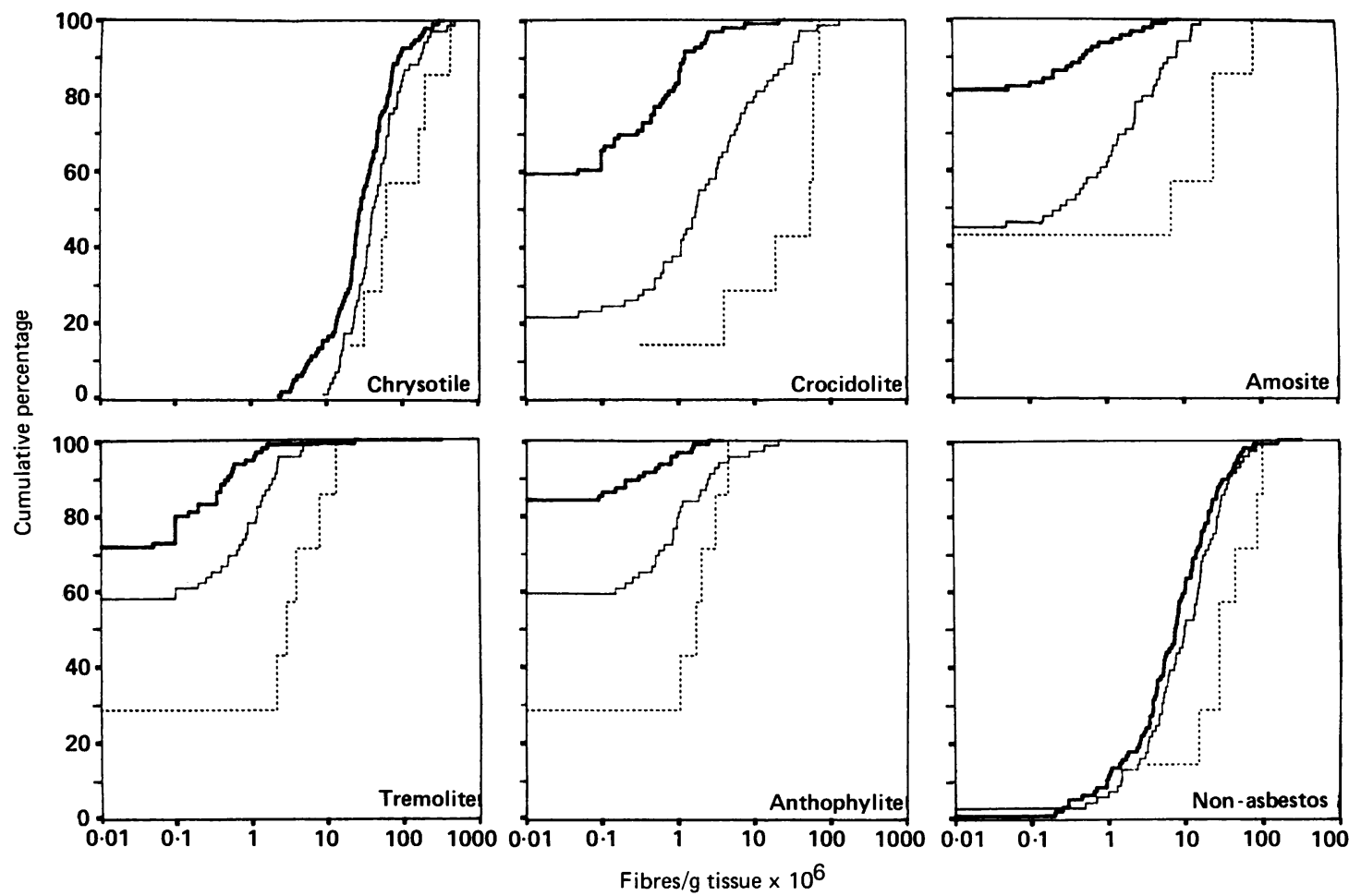

Figure 1 Mean fibre counts in lung tissue among asbestos cement workers with (----; $n=7)$ and without (-; $n=69)$ mesothelioma, and among controls ( $-; n=96)$.

ing, and counts of asbestos bodies). The Wilcoxon matched pairs ranked sign test was used to test the differences in concentrations of amphiboles in asbestos cement workers with, and a matched subset of those without, mesothelioma.

Logistic regression and multiple linear regression were used in the multivariate modelling of degree of fibrosis, and specific mineral content with adjustment for age and smoking. Fibrosis and content of mineral were generally dichotomised by presence or absence. When there was a sufficient range of nonzero values, the logarithm of the fibre concentrations was used as the dependent variable in the multiple linear regression.

\section{Results}

\section{MINERAL FIBRE CONTENTS}

The asbestos cement workers without mesothelioma had significantly higher numbers of total fibres, total asbestos fibres, chrysotile, and amphiboles (crocidolite, amosite, tremolite, and anthophyllite) compared with the controls (fig 1; all $\mathrm{p}$ values $\leqslant 0.004$, one-tailed tests). Among the exposed subjects, chrysotile was the dominant type of asbestos. The relative difference in amphibole, and especially crocidolite, content relative to the controls was much larger, although, out of all fibres, only a minor proportion were amphiboles. The asbestos cement workers also tended to have more non-asbestos fibres (mullite, $\mathrm{p}=0.07$; iron, rutile, muscovite, aluminium, and silicon, $p=0.05$ ) in their lungs than the controls.

Asbestos cement workers with mesothelioma had a significantly higher number of total fibres, all asbestos, crocidolite, tremolite, and anthophyllite concentrations compared with controls (fig 1 ; all $\mathrm{p}$ values $\leqslant 0.001)$. They also had higher amounts of chrysotile $(\mathrm{p}=0.01)$, mullite $(\mathrm{p}=0.004)$, and other nonasbestos fibres $(p=0.03)$.

Comparisons between exposed workers with and without mesothelioma showed significant differences for numbers of total fibres, all asbestos, and anthophyllite ( $p$ values $\leqslant 0.02$ ), and particularly for crocidolite $(p=0.003)$ and tremolite $(p=0.005$; fig 1). The cases of mesothelioma did not have significantly higher concentrations of chrysotile $(p=0.08)$ or amosite $(p=0.08)$. The mesothelioma cases, however, had started employment earlier, worked for a longer time, and also had a shorter time between cessation of exposure and death (table 1). To separate such differences from a possible difference in type of exposure, a rough matched analysis, including only workers employed for more than 20 


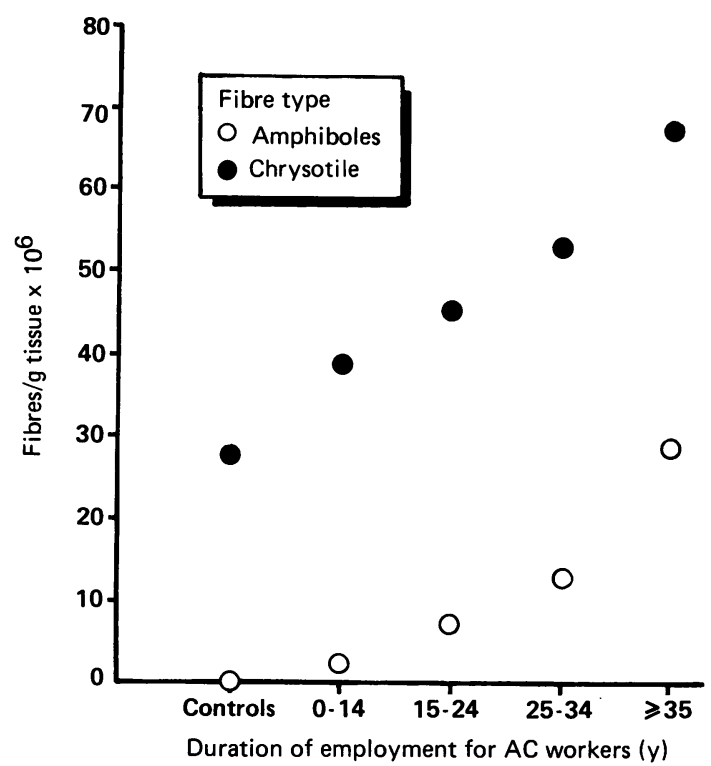

Figure 2 Median chrysotile and total amphibole counts by duration of employment for asbestos cement workers ( $A C$ workers) with and without mesothelioma $(n=76)$ and controls $(n=89)$.

years (calendar year of employment \pm 6 , duration of employment \pm 11 ), was performed. In six out of seven pairs, the worker without mesothelioma had lower amphibole counts than the case $(p=0.04$; Wilcoxon, two tailed).

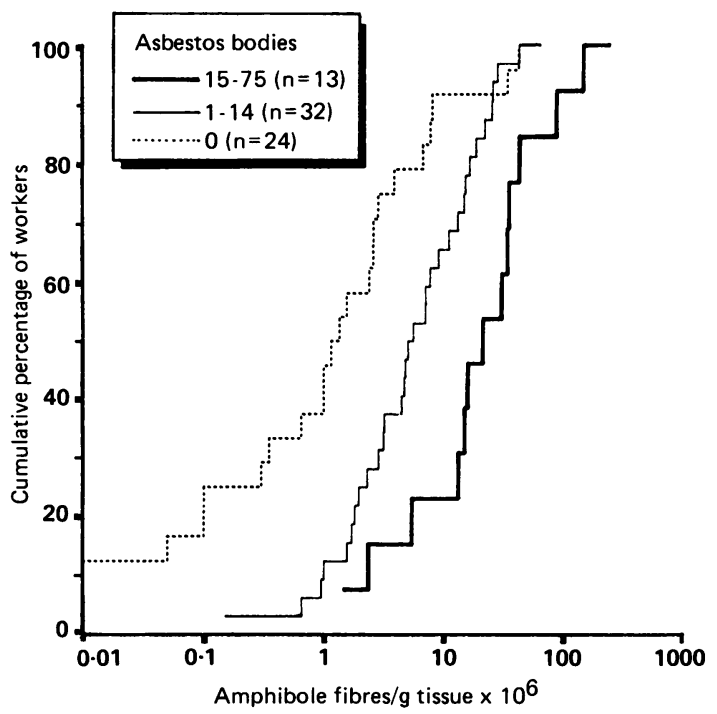

Figure 3 Cumulative distribution of 69 asbestos cement workers without mesothelioma according to amphibole content and asbestos bodies in the lungs.
Using the mass estimates of individual fibres and the fibre counts, the comparisons between the groups (asbestos cement workers with and without mesothelioma and controls), were repeated for total fibre and tutal amphiboles. Generally, the differences reported above were confirmed and strengthened, except for the matched test between tissue from workers with and without mesothelioma, which was not significant.

In the 76 asbestos cement workers, there was a significant relation between duration of employment and number of all asbestos fibres $(\tau=0 \cdot 2$, $\mathrm{p}=0.001$, one sided). The correlations were even stronger for the sum of amphibole fibres (fig 2; $\tau=0.4, p<0.001$ ), as well as for all the components tested separately. For the major fibre type, chrysotile, there was a non-significant tendency $(\tau=0.1, p=0.06)$. For mass of fibres, the correlations for total asbestos fibres $(\tau=0.4$, $\mathrm{p}<0.001)$ and total amphiboles $(\tau=0.5$, $\mathrm{p}<0.001)$ were strengthened.

\section{CONTENT OF MINERAL FIBRE AND HISTOPATHOLOGY Asbestos bodies}

There was a relation between the concentration of asbestos bodies and fibre counts and fibre mass among the 69 exposed persons without mesothelioma who were studied histologically. This was statistically significant for total asbestos fibres, as well as for the sum of amphibole fibres (fig 3; $\tau=0.5$, $\mathrm{p}<0.001)$ and all the particular amphiboles including tremolite $(\tau=0.3, \mathrm{p}<0.001)$. No correlation was found for chrysotile or non-asbestos fibres. No significant correlations were found among the controls. The results were similar using mass estimates and fibre counts.

\section{Fibrosis}

The correlations between the degree of fibrosis and the fibre counts and mass were generally weak, both among the asbestos cement workers and the controls (table 2). Among the exposed persons no statistically significant dose response relations were found. Only tendencies were seen for the sum of amphiboles and tremolite (table 2, fig 4). Surprisingly, the correlations found for these groups of fibres among the controls were statistically significant (fig 4). No correlations were found between chrysotile (fig 4) or non-asbestos fibres and fibrosis, either among the exposed workers or among the controls.

Smoking habits were known for $66(96 \%)$ of the asbestos cement workers. In these, the relations between chrysotile, commercial (crocidolite and amosite) amphibole or tremolite contents, smoking and age on the one hand, and fibrosis on the other, were studied in detail by logistic regression. In this analysis, the actual fibre counts were used, whereas fibrosis was dichotomised. There was no significant 
Table 2 Association between degree of fibrosis and chrysotile, amphibole, and tremolite contents, smoking habits and age among controls and asbestos cement workers without mesothelioma (Kendall's rank correlation coefficients, one tailed tests)

\begin{tabular}{|c|c|c|c|c|}
\hline \multirow[b]{2}{*}{ Parameter } & \multicolumn{2}{|c|}{ Controls $(n=89)$} & \multicolumn{2}{|c|}{$\begin{array}{l}\text { Asbestos cement } \\
\text { workers }(n=69)\end{array}$} \\
\hline & $\tau$ Value & p Value & $\tau$ Value & p Value \\
\hline $\begin{array}{l}\text { All asbestos: } \\
\text { Count } \\
\text { Mass estimate } \\
\text { Chrysotile count } \\
\text { Amphiboles: } \\
\text { Total count } \\
\text { Mass estimate } \\
\text { Tremolite count } \\
\text { Anthophyllite count } \\
\text { Amosite count } \\
\text { Crocidolite count } \\
\text { Non-asbestos fibre count } \\
\text { Smoking (pack-years) } \\
\text { Age }\end{array}$ & $\begin{array}{l}0.15 \\
0.18 \\
0.21 \\
0.04 \\
0.13 \\
0.07 \\
0.05 \\
0.2^{\star} \\
0.08\end{array}$ & $\begin{array}{l}0.04 \\
0.02 \\
0.01 \\
0.3 \\
0.09 \\
0.3 \\
0.3 \\
0.04 \\
0.2\end{array}$ & $\begin{array}{l}0.12 \\
0.11 \\
0.16 \\
0.09 \\
0.08 \\
0.09 \\
0.09 \\
0.07 \dagger \\
0.06\end{array}$ & $\begin{array}{l}0.09 \\
0.1 \\
0.06 \\
0.2 \\
0.2 \\
0.2 \\
0.2 \\
0.2 \\
0.3\end{array}$ \\
\hline
\end{tabular}

*For the 66 workers with known smoking habits.

†For the 64 controls with known smoking habits. association between concentrations of chrysotile ( $p=0.9$, two-tailed) or the sum of concentrations of crocidolite and amosite $(p=0.2)$ and increased probability of fibrosis. When more pronounced fibrosis (grades 2-4) was compared with none or slight (grade 1), there was a statistically significant association with crocidolite and amosite concentrations $(p=0.02)$. Furthermore, content of tremolite displayed a clear relation with presence of fibrosis $\left(\chi^{2}=4.9, p=0.003\right)$.

The analysis was repeated, using masses of total asbestos fibres and all amphiboles. The only difference compared with the use of fibre counts was that the significant association between concentration of amphiboles and pronounced fibrosis was not reproduced.

Neither degrees of smoking nor age were associated with fibrosis.

Among the controls, $64(72 \%)$ had known smoking habits. In this subgroup, fibrosis (grades 1-4 $v$ none), as well as the amphibole and tremolite con-

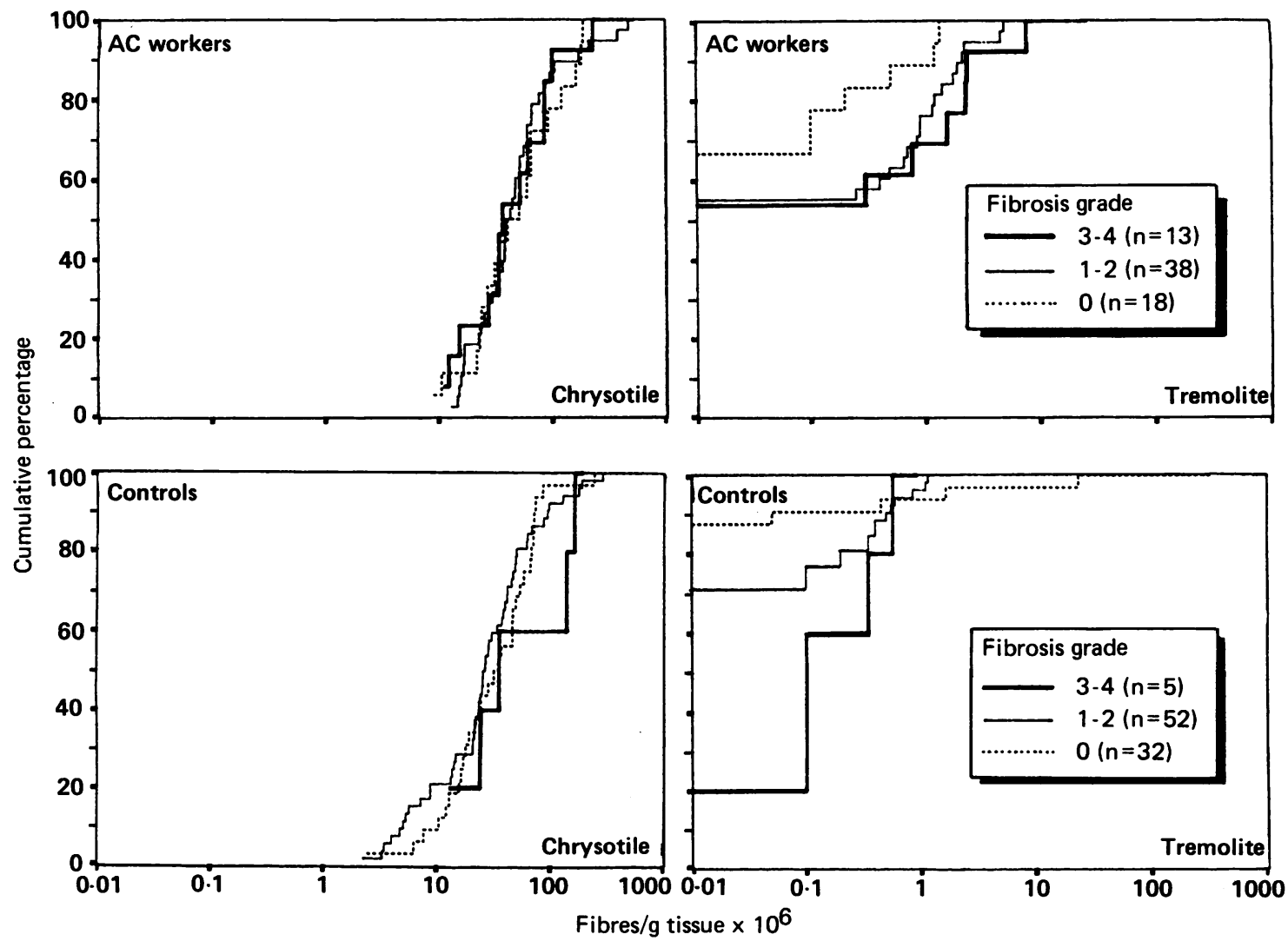

Figure 4 Cumulative distribution of asbestos cement workers and controls according to chrysotile and tremolite content, by grade of fibrosis. 
tents (present or absent), were dichotomised because of their low incidence in the control subjects.

The occurrence of amphiboles (all types) was associated with a significantly increased probability of presence of fibrosis $\left(\chi^{2}=5.0, p=0.03\right)$. This association was most pronounced among non-smokers and subjects who smoked less than 20 pack-years $\left(\chi^{2}=7 \cdot 9, p=0 \cdot 005\right)$. No corresponding significant association for presence of tremolite $(p=0.1)$ or for the concentration of chrysotile $(p=0.2)$ existed in the total group. Among non-smokers and smokers with a tobacco consumption of less than 20 packyears, however, there was an effect of tremolite $\left(\chi^{2}=5.3, p=0.02\right)$. Further, there was a significant association between amount of smoking and increasing probability of fibrosis $\left(\chi^{2}=4 \cdot 2, p=0.04\right)$. This was due mainly to an association in the subjects without amphibole fibres $\left(\chi^{2}=6 \cdot 7, p=0.01\right)$.

\section{Fibre counts and background factors}

Nó group of fibre counts was significantly associated with tobacco consumption among the asbestos cement workers when age, intensity, and duration of employment were adjusted for in a logistic regression. Age displayed a tendency towards a positive association with concentrations of chrysotile $(p=0.06)$, but not with other fibres.

Among the controls, tobacco consumption was significantly related to the presence of tremolite $\left(\chi^{2}=7 \cdot 7, p=0.005\right)$, but not to the presence of chrysotile $(p=0.4)$, or presence of amphiboles $(p=0 \cdot 08)$. Age had no significant effect.

\section{Discussion}

\section{FIBRE COUNTS}

The specimens were collected retrospectively from routine necropsies, often without information about from which part of lung the tissue had been taken. As long as this is done randomly in relation to exposure state, it will increase the variation and, therefore, increase the difficulties in establishing correlations with exposure. The possibility of a non-random sampling must also be considered. Asbestotic lesions are often located peripherally and in the lower lobes, and these sites tend to have higher counts of fibres (about 20\% higher than the rest of the lung) and asbestos bodies. ${ }^{17}$ It is possible that, due to macroscopic changes, the tissue was sampled from these parts among some of the exposed workers. This would increase the differences between the exposed persons and the controls. It is, however, highly unlikely that this explains differences of the magnitude we have found.

The filter preparation for TEM is complicated. Loss of material can occur at several stages, and fibre bundles can split up. The magnitude of this effect might differ for the different types of fibre and cause false fibre counts. The material from the exposed and the control groups was handled and analysed in parallel and in the same way, but our results cannot be directly compared with materials from other laboratories, because of considerable interlaboratory variation. $^{18}$

In the statistical analysis, fibre counts and mass estimates for total fibres and all amphiboles were used in parallel. The results using fibre counts and mass estimates were similar, although the mass estimates generally tended to strengthen the differences between the groups.

Fibre counts among the asbestos cement workers were, as expected, higher than among the controls. The major fibre was chrysotile, which is in accordance with the use of asbestos in the factory. Chrysotile has a relatively short persistence in lung tissue. ${ }^{4}$ It may, therefore, be assumed that a large part of the chrysotile, primarily deposited in the lung, had been cleared in the period from cessation of exposure to death. The chrysotile counts among the "unexposed" controls were surprisingly high compared with other controls (from the United States) studied by the same laboratory, ${ }^{19}$ indicating that the average Swede might have an exposure to chrysotile that is not negligible.

A marked difference in amphibole content was found between the exposed and the control groups. The ratio between amphibole and chrysotile fibres in lung tissue in the exposed group was higher than the estimated proportion used in production, but chrysotile was still the predominant fibre (in terms of number of fibres) in the exposed group. Considering that amphiboles accumulate in lung tissue to a much larger extent than chrysotile, ${ }^{4}$ this indicates that exposure to amphiboles constituted a very small part of the total exposure to asbestos at the plant.

In the controls, there was a significant association between smoking and content of tremolite. These findings are difficult to interpret and do not give any clear evidence for an increased deposition or decreased clearance among the smokers, especially as no such relation was found in the exposed group or for any other type of fibre.

Strong dose response relations were found between duration of exposure and concentration of commercial amphibole fibres in the lung, but not for the less persistent chrysotile fibres. The non-commercial amphiboles (tremolite and anthophyllite), frequently present in chrysotile ore, did, however, display a correlation with duration of exposure. This association was independent of age. It is thus possible that these minerals, in a known industrial setting, could be used as a rough indirect measurement of the accumulated exposure to chrysotile, although some data suggest that processing of chrysotile would remove part of the tremolite contamination..$^{20}$ This issue does, however, need further investigation. 


\section{ASBESTOS BODIES}

A good correlation was also found between the number of asbestos bodies detected with light microscopy and fibre counts and mass (TEM) for commercial, as well as non-commercial, amphiboles. This is in accordance with the fact that asbestos bodies form mainly around amphibole fibres, ${ }^{21}{ }^{22}$ but in these studies correlations were found only between the commercial amphiboles and asbestos bodies. The present study indicates that counting of asbestos bodies by light microscopy with unstained sections $25 \mu$ thick, may be useful not only as a crude estimate of exposure to amosite and crocidolite, but also to chrysotile with tremolite contamination.

\section{FIBROSIS}

The relative fibrogenicity of the different types of asbestos in humans is not fully known. In the textile industry, using only chrysotile, an association was found between fibrosis and the content of chrysotile in lung tissue. ${ }^{19}$ Among dockyard workers, probably with a substantial exposure to amphiboles, no association was found between the chrysotile count in lung tissue and fibrosis, whereas such associations were found for both amosite and crocidolite. ${ }^{23}$ In this study, no correlations were found between the chrysotile content and the degree of fibrosis among the exposed workers. For crocidolite and amosite a weak association was found only when more pronounced fibrosis was compared with no or slight fibrosis. Our assessment of the fibrogenic effect of these fibres was, however, limited as few workers had a high exposure to them.

A significant correlation was established with the amount of tremolite. This association could arise from the lower clearance rate, but the persistence of these fibres may also make them particularly fibrogenic. In Canadian chrysotile mines around $1.5 \%$ of the airborne fibres are tremolite and studies of lung tissue from the miners actually showed higher amounts of tremolite than chrysotile fibres, ${ }^{4024}$ whereas workers exposed to chrysotile in other industrial settings usually have more chrysotile than tremolite fibres in their lungs. ${ }^{20}$ Associations between the content of tremolite and fibrosis have been found among chrysotile textile workers, ${ }^{19}$ and the association was stronger than with chrysotile. Tremolite with a high aspect ratio, as the only known mineral fibre to which workers were exposed, has also been associated with fibrosis. Thus workers engaged in mining of vermiculite contaminated with tremolite, and populations in Greece with environmental exposure to whitewash containing tremolite, had parenchymal changes on $x$ ray film suggesting fibrosis. ${ }^{25}{ }^{26}$ Together, these results confirm that tremolite accumulates in lung tissue and indicate that tremolite, as well as the commercial amphiboles (amosite and crocidolite), may have a stronger fibrogenic effect than chrysotile.

The association, found among the controls, between concentrations of all amphiboles and tremolite, and fibrosis was not expected. Furthermore, a more thorough analysis showed that smoking was correlated with fibrosis and the fibrogenic effect of the commercial amphiboles and tremolite was evident only among the non- and light smokers. This finding is surprising in a group, which, to our knowledge, had no extensive occupational exposure. The amphibole (especially tremolite) concentrations, were generally low, although the amount of tremolite in one of the control subjects (a farmer) was so outstanding, as to suggest a significant exposure (powdered dolomite used in the fields?). It is noteworthy that the association between tremolite and fibrosis was even stronger when he was excluded. From the present data, it cannot be judged whether the fibres accumulated first, causing fibrosis, or if the fibrosis occurred first, causing a deterioration of the alveolar clearance of fibre particles. Moreover, analysis on total dust was not performed and therefore the relation between the total material retained in the lung and the content of tremolite could not be assessed.

\section{MESOTHELIOMA}

There were interesting differences in the contents of crocidolite and tremolite between asbestos cement workers with and without mesothelioma. These observations are in agreement with the findings reported from Canada, ${ }^{27}$ and the United Kingdom, ${ }^{2}$ where the cases of mesothelioma had higher concentrations of amphiboles in lung tissue than matched controls, whereas no difference in the content of chrysotile was establisined.

The differences in content of amphiboles between mesothelioma cases and non-mesothelioma cases in our study could only partly be explained by background factors (duration of exposure, calendar year of onset of employment, time between cessation of exposure and death). After accounting for these factors in a roughly matched case-referent analysis, the cases still had a higher amphibole count than the non-cases in six out of seven pairs.

The work was supported by grants from the Swedish Work Environment Fund.

Requests for reprints to Dr Maria Albin, Department of Occupational and Environmental Medicine, University Hospital, S-221 85 Lund, Sweden.

1 Johansson L, Albin M, Jakobsson K, Welinder H, Ranstam J, Attewell $R$. Ferruginous bodies and pulmonary fibrosis in dead low to moderately exposed asbestos-cement workers; histological examination. Br J Ind Med 1987;44:550-9.

2 Wagner JC, Pooley FD, Berry G, et al. A pathological and 
mineralogical study of asbestos-related deaths in the United Kingdom in 1977. Ann Occup Hyg 1982;26:423-31.

3 Todd JC. Sharp competition for shagging markets in 1981. Engineering and Mining Journal March, 1982:125-7.

4 Sébastien P, Bégin R, Case BW, McDonald JC. Inhalation of chrysotile dust. In: Wagner JC, ed. Biological effects of chrysotile. (Accomplishments in Oncology, Vol 1 No 2). Philadelphia: Lippincott, 1986:19-29.

5 Pooley FD, Mitha R. Determination and interpretation of the levels of chrysotile asbestos in lung tisue. In: Wagner JC, ed. Biological effects of chrysotile. (Accomplishments in Oncology, Vol 1 No 2) Philadelphia: Lippincott, 1986:12-8.

6 Gylseth B, Mowe G, Wannag A. Fibre type and concentration in the lungs of workers in an asbestos-cement factory. $\mathrm{Br} \mathrm{J}$ Ind Med 1983;40:375-9.

7 Albin M, Jakobsson K, Attewell R, Johansson L, Welinder H. Mortality and cancer morbidity in cohorts of asbestos cement workers and referents. Br J Ind Med 1990;47:602-610.

8 Dement JM, Harris RL, Symons MJ, Shy CM. Exposures and mortality among chrysotile asbestos workers. Am J Ind Med 1983;4:421-33.

9 McDonald AD, Fry JS, Woolley AJ, McDonald JC. Dust exposure and mortality in an American chrysotile textile plant. Br J Ind Med 1983;40:361-7.

10 Finkelstein $M$. Mortality among long-term employees of an Ontario asbestos-cement factory. $\mathrm{Br} J$ Ind Med 1983;40: 138-44.

11 Ohlson CG, Hogstedt C. Lung cancer among asbestos cement workers. A Swedish cohort study and a review. $\mathrm{Br} J$ Ind Med 1985;42:397-402.

12 Gardner MJ, Winter PD, Pannett B, Powell CA. Follow up study of workers manufacturing chrysotile asbestos cement products. Br J Ind Med 1986;43:726-32.

13 Hughes JM, Weill H, Hummad YY. Mortality of workers employed in two asbestos cement manufacturing plants. $\mathrm{Br} \mathrm{J}$ Ind Med 1987;44:161-74.

14 McDonald JC, Liddell FDK, Gibbs GW, Eyssen GE, McDonald AD. Dust exposure and mortality in chrysotile mining, 1910-75. Br J Ind Med 1980;37:11-24.

15 Pooley FD, Clark NJ. Quantitative assessment of inorganic fibrous particulates in dust samples with an analytical transmission electron microscope. Ann Occup Hyg 1979;22:253-71.

16 Hinson KFW, Otto H, Webster I, Rossiter CE. Criteria for the diagnosis and grading of asbestosis. In: Bogovski P, Gilson JC, Timbrell V, Wagner JC, eds. Biological effects of asbestos. Lyon: IARC, 1973:54-7.

17 Sébastien P, Fondimare A, Bignon J, Monchaux G, Desbordes $\mathrm{J}$, Bonnaud G. Topographic distribution of asbestos fibres in human lung in relation to occupational and non-occupational exposure. In: Walton WH, ed. Proceedings of 4th international symposium on inhaled particles, Edinburgh, 1975. Part 2. Oxford: Pergamon Press, 1977:435-44.

18 Gylseth B, Churg A, Davis JMG, et al. Analysis of asbestos fibers and asbestos bodies in tissue samples from human lung. An international interlaboratory trial. Scand $J$ Work Environ Health 1985;11:107-10.

19 Green FHY, Harley R, Vallyathan V, Dement J, Pooley FD, Althouse R. Pulmonary fibrosis and asbestos exposure in chrysotile asbestos textile workers. In: Wagner JC, ed. Biological effects of chrysotile. (Accomplishments in Oncology, Vol 1 No 2) Philadelphia: Lippincott, 1986:59-68.

20 Churg A. Crysotile, tremolite, and malignant mesothelioma in man. Chest 1988;93:621-8.

21 Roggli VL, Pratt PC, Brody AR. Asbestos content of lung tissue in asbestos associated diseases: A study of 110 cases. Br J Ind Med 1986;43:18-28.

22 Warnock ML, Wolery G. Asbestos bodies or fibers and the diagnosis of asbestosis. Environ Res 1987;44:29-44.

23 Wagner JC, Moncrieff CB, Coles R, Griffiths DM, Munday DE. Correlation between fibre content of the lungs and disease in naval dockyard workers. $B r J$ Ind Med 1986;43:391-5.

24 Pooley FD. An examination of the fibrous mineral content of asbestos lung tissue from the Canadian chrysotile mining industry. Environ Res 1976;12:281-98.

25 Langer AM, Nolan RP, Constantopoulos SH, Moutsopoulos HM. Association of Metsovo lung and pleural mesothelioma with exposure to tremolite-containing whitewash. Lancet 1987;i:965-7.

26 McDonald JC, Sebastien P, Armstrong B. Radiological survey of past and present vermiculite miners exposed to tremolite. Br J Ind Med 1986;43:445-9.

27 McDonald AD, Armstrong B, Case B, et al. Mesothelioma and asbestos fiber type. Evidence from lung tissue analysis. Cancer 1989;63:1544-7.

Accepted 30 April 1990 